INTERNATIONAL JOURNAL OF RESEARCHES IN BIOSCIENCES, AGRICULTURE AND TECHNOLOGY

(C) VISHWASHANTI MULTIPURPOSE SOCIETY (Global Peace Multipurpose Society) R. No. MH-659/13(N) www.vmsindia.org

\title{
STUDY OF QUALITATIVE DIVERSITY OF ROTIFER COMMUNITY OF FRESHWATER KATEPURNA RESERVOIR, DISTRICT AKOLA, MAHARASHTRA, INDIA
}

\author{
Jaya R., Pawar and Dilip S. Dabhade
}

R.A. Arts, Shri. M.K.Commerce and Shri. S.R. Rathi Science College, Washim. 444505, jayapawar8@gmail.com

Abstract:

The biodiversity of the rotifer fauna of Katepurna reservoir was studied by monthly sampling advocated from July 2013 to August 2015. Remarkably rich rotifer community consisting of 20 species. In the present study the total Rotifers are represented by 7 families including 2 sub-families and 9 genera consisting of 20 species was recorded. Keywords: Rotifers, biodiversity, Katepurna reservoir, Trophic level.

\section{Introduction:}

Since late 1070's, studies of rotifer diversity attract attention worldwide. For evaluating environmental changes; understanding the functional properties of rotifer fauna are important (Bledzki and Elison, 2003). Rotifers address its ecological importance in aquatic environments, filtering suspended material of different sizes and advocate new methods to obtain their food, to classify as generalists or specialists (Sonia and Ramanibai, 2012). They play an important link in energy flow and nutrient cycling because of their high population renewal rates. Rotifera is one of the fascinating group of zooplankton on the aquatic ecosystem. Rotifers occur almost universally in freshwater habitat and make an important group of zooplankton community.

The rotifers are microscopic soft bodied freshwater invertebrates. Their distribution and ecology have interesting evolutionary implications (Krishnamoorthy and Sakhivel, 2007). Rotifers are remarkable indicators of trophic status of water body. The abundance of rotifers is more or less governed by interaction of number of physical and chemical and biological processes and is related to the suitable conditions for their survival in the water.

The present study concentrates on the biodiversity of rotifer fauna of Katepurna reservoir with reference to their role at trophy level.

\section{Material and Methods:}

Katepurna Reservoir: The Katepurna reservoir is the construction on the Katepurna which is originated from Kata village located near Washim City. The flowing direction of the Katepurna river is from South to North and longitude is 20-28'-30" whereas latitude is7709'-00".The area under investigation is a part of Purna river basin, of
Which Katepurna river is one of the major tributaries, covering part of Washim and Akola dist.

The Katepurna reservoir is a perennial reservoir, such reservoir contains water throughout the year. The main aim of the construction of Katepurna reservoir is to provide sufficient water for some purposes such as drinking, washing and fishing activities in relation to maintain the economical employment to the fisherman.

Monthly collection of zooplankton was carried out from four different sites of the reservoir by using the Nylon Plankton Net of mesh size $25 \mu$. To preserve the Qualitative samples, the samples were fixed by adding equal volume of hot water followed by $4 \%$ formalin, few drops of glycerin to keep the sample away from the evaporation. To avoid the clumping few drops detergent were added in these samples. The identification of the rotifer species were evaluated by using the literature of Dhanapati, 2000, Edmondson, (1959). Observation of rotifers was done under the Olympus Phase Contrast Microscope and Coslab digital camera DC 10+ was used for their photography.

\section{Result and discussion:}

In the present study the total Rotifers are represented by 7 families including 2 subfamilies and 9 genera consisting of 20 species which are Brachionus diversicornis, Brachionus falcatus, Brachionus caudatus, Brachionus forticula, Brachionus calyciflorus varhymani, Brachionus calyciflorus vardorcas, Keratella tropica, Keratella cochlearis, Keratell avalga, Colurella obtusa, Lecane cornuta, Lecane curvirostris, Lecane tesselata, Lecane pyriformes, Trichocerca rattus Asplanchna priodonta, Asplanchn abrightwelli, Asplanchna sieboldi, Filinia opoliensis, Lindia intermidia, Pseudoembata acutipoda, etc. 


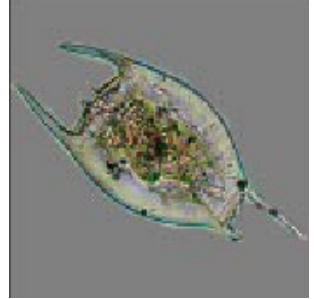

Fig. A- Brachionus Diversicornis

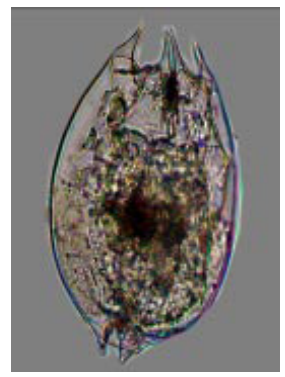

Fig. D-Brachionus calyciflorus $v$. dorcas

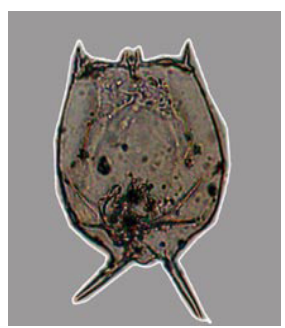

Fig. H- Brachionus caudatus

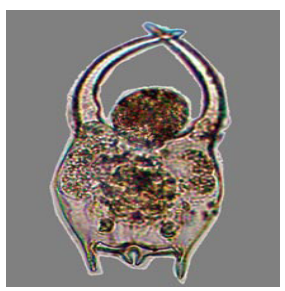

Fig. L- Brachionus forticula with egg

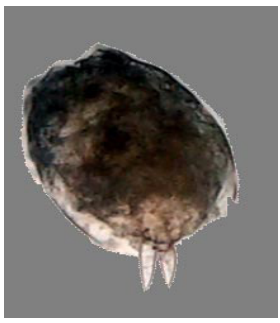

Fig.P-Colurella obtuse

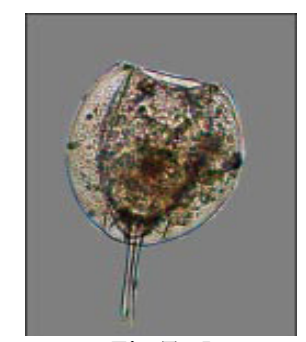

Fig.T- Lecane Tesselata

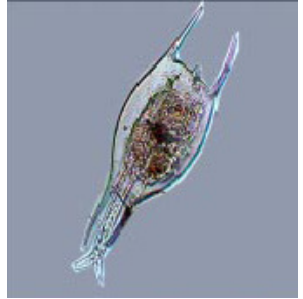

Fig. B-Brachionus diversicornis with foot

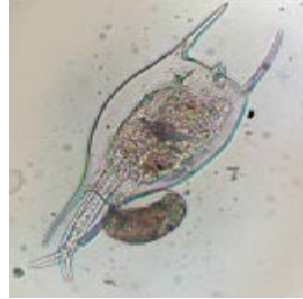

Fig. C- Brachionus diversicornis with foot and egg

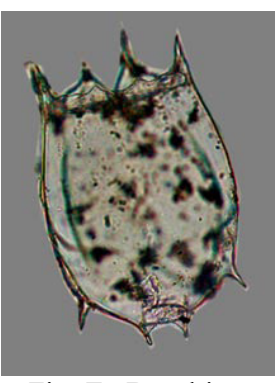

Fig. E- Brachionus calyciflorus

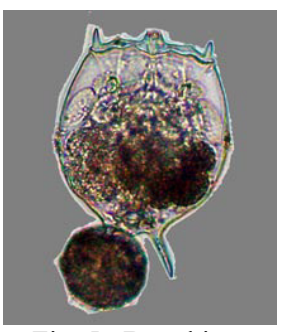

Fig. I- Brachionus caudatus with egg

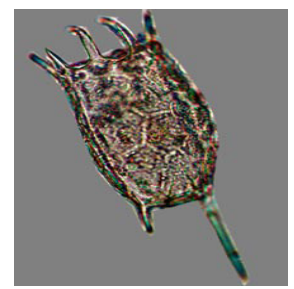

Fig.M-Keratella tropica

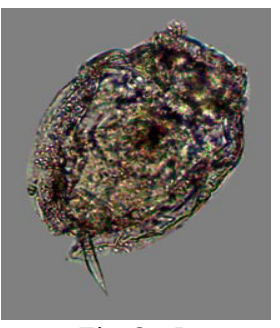

Fig.Q- Lecane pyriformes

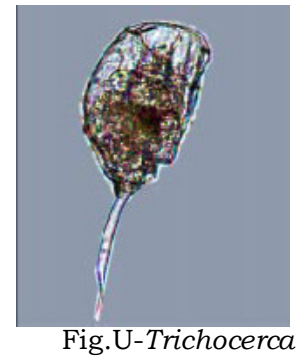
rattus

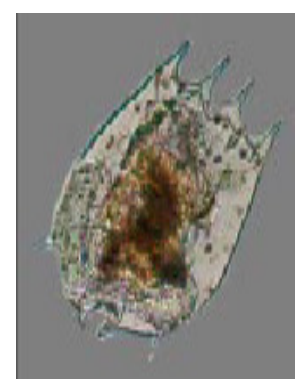

Fig. F- Brachionus calyciflorus

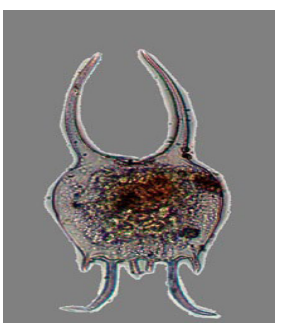

Fig. J-Brachionus fulcatus

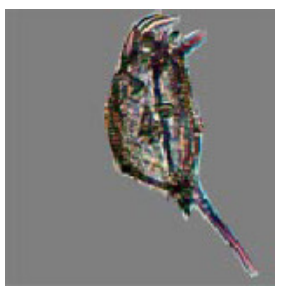

Fig. N-Keratella cochlearis

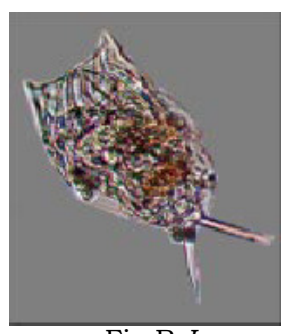

Fig.R-Lacane curvicornis

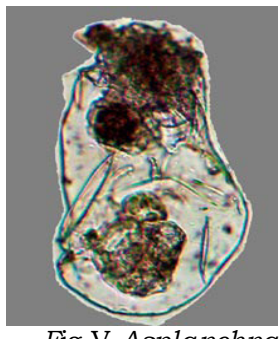

Fig.V-Asplanchna

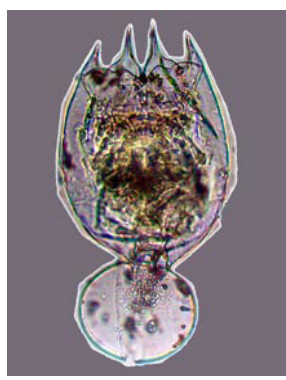

Fig.G-Brachionus calicyflorus $v$. dorcasw

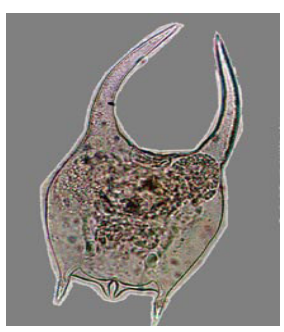

Fig. K-Brachionus forticula

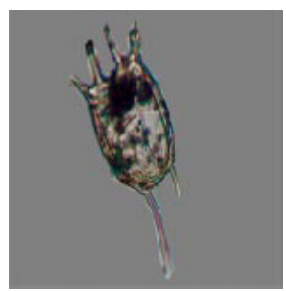

Fig. O-Keratella valga

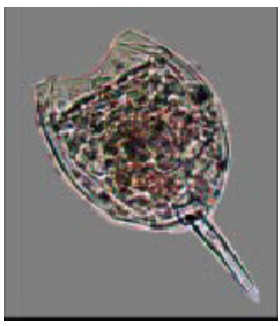

Fig.S-Lecane cornuta

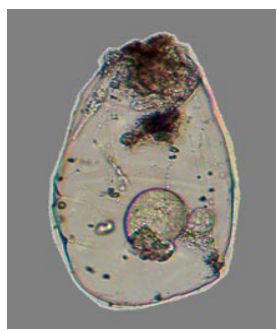

Fig.W- Asplanchna 


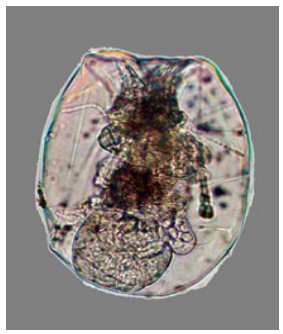

Fig. X- Asplanchna Priodonta

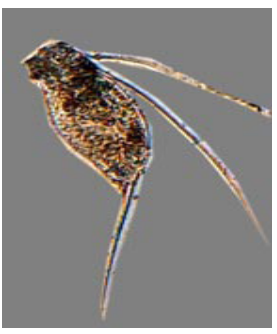

Fig. Y- Filinia opoliensis

Filinia opoliensis was the species of rotifer which was observed only during the summer months of both years and the similar observations are given by Dede and Deshmukh (2015). Filinia has observed as most sensitive form and such observation was also opined by Palhrya and Malviya (1988) during the study of Narmada river at Hoshangabad in Madhya Pradesh. In the present study the Brachionus fulcatus and Keratella tropica was found maximum during the month of November of both years. This observations favour with the work of Ghantaloo (2011).

In the present study the Brachionus and Keratella found as the dominant species of rotifera. According to Goel and Charan (1991) these are the pollution tolerant species and indicate accumulation of organic matter.

Asplanchna priodonta was absent in November month of both years and keratella tropica was absent in the month of December and in June during 2013-14 and in January and July of 2015, Monostyla lunaris was absent in August, September and October during the first year and in August and September of during second year, Keratella valga was found absent in June and July during first year 2014 and during second year in August 2014. Keratella cochlearis is marked as absent species during month of April, May, June and July of 2014 (first year) and July 2015(Second year), all these results are similar with the findings of Beraet al., (2014) During the study the Trichocerca species is mostly observed in rainy season. Brachionus calyciflorus and Keratella tropica were most dominant species in the alkaline water, this result agrees with the study of Halvorsen (2004) and Vasisht (1968).

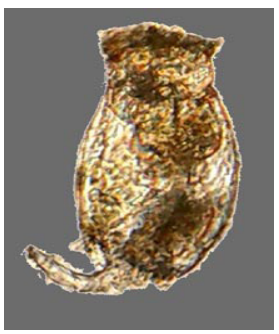

Fig. Z- Pseudoembata acutipoda

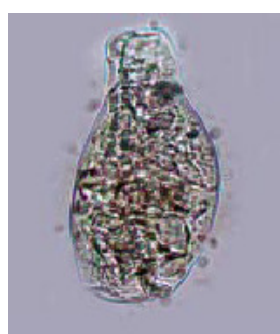

Fig. Z1- Lindia selenura

\section{Conclusion:}

Brachionus calyciflorus species of rotifera is a indication of eutrophication. The rotifers performs a vital role at the trophic level of freshwater impoundments and serves as living capsules of eutrophication.

\section{References:}

Bera, A.; T.K. Dutta, Patra B. C. and Sar U.K. (2014): A study of zooplankton biodiversity of Kangsabati Resrvoir, W.B., India. Int. J. of Develop. Res. 4(11), pp. 2431-2436.

Bledzki and Ellison (2003): Diversity of rotifers from north eastern U.S.A. bogs with new species records for North America and New England. Hydrobiologia 497: 53-62.

Dede, A.N. and Deshmukh A.N. (2015): Study on Zooplankton Composition and Seasonal Variation in Bhima River NearRamwadi Village, Solapur District (Maharashtra), India. Int.J.Curr. Microbiol.App.Sci. 4(3): 297-306

Ghantaloo, U.S, Sarwade J.P., Gaikwad A.F. and Kamble A.F. (2011): Study of zooplankton diversity of Nira Left Bank Canal Shardanagar Tal BaramatiDist Pune with Reference to Physico-chemical parameters. Recent Research in Science and Technology, 3(3): 125128.

Goel, P.K. and Charan V.R. (1991): Studies on the limnology of polluted fresh water tank, InB. Gopan and V. Asthana (Eds).Aquatic Sciences in India (pp 51-64), Indian Association for Limnology and Oceanography.

Halvorsen, G. (2004): Hydrobiol. 521: 149-179.

Krushnamoorthy, K, Rajlakshmi $K$ and Sakhivel $D$. (2007): Diversity of zooplankton in Mangrove Areas of Puducherry, India, J. Aquatic Bio. Vol. 22(1) PP 45-48.

Palharya, J.P. and Malviya S. (1988): Pollution of the Narmada river at Hoshangabad in Madhya Pradesh and Suggested Measures of Control. In: Ecology and pollution of Indian river (Ed; R.K. Teivedy).Ashish Publishing House, New Delhi, India, pp. 54-85.

Sonia R. and R. Ramanibai (2012): Diversity of rotifer fauna of Kolavoi Lake, Chingleput district, Tamil Nadu. J. of Research in Biology, 1: 028-031. Vasisht, H.S. (1968):Proc. Symp. Rec. Adv. Tropical Ecology. 9: 316-325. 